\title{
RELATIONSHIP OF CORPORATE AND PRODUCT IMAGES WITH UTILIZATION OF BASIC EMERGENCY OBSTETRIC-NEONATAL SERVICES IN DELI SERDANG, NORTH SUMATERA
}

\author{
Winda Novita1), Destanul Auliaa), Juanita ${ }^{2)}$ \\ ${ }^{1)}$ Masters Program in Public Health, Universitas Sumatera Utara \\ ${ }^{2)}$ Department of Health Policy and Administration, \\ Faculty of Public Health, Universitas Sumatera Utara
}

\begin{abstract}
Background: Approximately $15 \%$ of expected births worldwide will result in lifethreatening complications during pregnancy, delivery, or the postpartum period. Providers skilled in emergency obstetric and newborn care (EmONC) services are essential, particularly in countries with a high burden of maternal and newborn mortality, including Indonesia. This study aimed to determine the relationship of corporate image and product image with utilization of EmONC services in Deli Serdang, North Sumatera.

Subjects and Method: This was a cross-sectional study conducted at Hamparan Perak, Deli Serdang, North Sumatera. A total of 100 pregnant mothers were selected for this study. The dependent variable was utilization of EmONC. The independent variables were corporate image and product image. The data were collected by questionnaire. The data were analyzed by a multiple logistic regression.

Results: Utilization of EmONC increased with good corporate image (OR= 23.90; $95 \% \mathrm{CI}=4.45$ to $128.21 ; \mathrm{p}=0.001)$ and good product image $(\mathrm{OR}=41.82 ; 95 \% \mathrm{CI}=$ 7.81 to $223.93 ; \mathrm{p}=0.001)$. The two independent variables in the model explained $70 \%$ of the variation in the utilization of EmONC.

Conclusion: Utilization of EmONC increases with good corporate image and good product image. Management can further improve EmONC image and its services to increases utilization.
\end{abstract}

Keywords: corporate image, product image, emergency, obstetric-neonatal service.

\section{Correspondence:}

Winda Novita. Masters Program in Public Health, Universitas Sumatera Utara, Jl. Dr. T. Mansur No. 9, Padang Bulan, Medan, North Sumatera.

Email:wndnvt@yahoo.com. Mobile: 081360996023 